\title{
Shenzhen Bay Flying Swallow Type Composite Arch Bridge Design
}

\author{
Yong.Li ${ }^{1,2, a}$, Xiao.Xiong.Zha ${ }^{2, b}$, CHong.Li.Zhu ${ }^{1,2, c}$ \\ ${ }^{1}$ Shenzhen Bridge Doctor Design and Institute Co. Ltd, Shenzhen 518049, P. R. China; \\ ${ }^{2}$ Harbin Institute of Technology Shenzhen Graduate School, Shenzhen 518055, China; \\ a Liy2000@163.com, bhahero@126.com, ${ }^{\mathrm{c} 963066363 @ q q . c o m ~}$
}

\begin{abstract}
Based on the Shenzhen Bay Bridge which is located at the center of park cultural landscape, so it has important requirements of improving environments, protecting the environment and beautifying the environment. the bridge is optimal designed to be a flying swallow type curve specialshaped composite arch bridge. The difficult question that on the condition of ocean foundation, the curve beam through tensing the tie bar can't eliminate the horizontal thrust was solved through the conjoined main and deputy arch are the same goals and supplement and complement to each other. Increasing ties between arch rib through the wind bracing and using corrugated steel-web and cantilever truss composite structure to form the longitudinal box girder, which increase the bridge deck width and improve the stability of bridge structure. The plane curve girder is united with arch rib by single cable plane suspender to form a space curve, which solves the torsional problems of single cable plane curve beam. and avoids the staggered messy visual of double cable plane. Box-girder bridge with corrugated steel webs- truss composite compared to traditional pre-stressed concrete box girder, which can reduce the dead weight of beams and solves the problem that the traditional prestressed concrete box girder web plate is easy to crack, and so on. Flowing curve modelling adds to the beauty of the city of Shenzhen. In design, it takes into account the traffic function, and fully embodies the times tinge of modern bridges in the urban landscape,it provides a new ideas for large span curve special-shaped composite arch bridge.
\end{abstract}

Key words- special-shaped composite arch bridge; curve beam; corrugated - truss composite structure; single cable plane; box girder

\section{Project BACKGROUND}

Shenzhen bay bridge is located in the boundary between lake park and the shenzhen bay, facing shahe west road, backed by "spring cocoon"of the shenzhen bay sports center and across the mouth of lake park. The bridge is flying swallow type curve special-shaped composite arch bridge.the medial and lateral main arch span is $176.26 \mathrm{~m}$ and $164.40 \mathrm{~m}$, respectively. The half-through arch bridge is $230.50 \mathrm{~m}$ long and span of curve girder is $30.25 \mathrm{~m}+170.00 \mathrm{~m}$ $+30.25 \mathrm{~m}$, The main girder is the corrugated steel webs and truss composite structure, which were $2.25 \mathrm{~m}$ high and 10 meters wide. The center line of the main girder is composed of a curve of the curvature radius $154.41 \mathrm{~m}$ and a curve of the curvature radius $188 \mathrm{~m}$. Bridge deck longitudinal slope is controlled by $5 \%$, bidirectional transverse slope is controlled by $1 \%$, approach bridge is smoothly connected with the planning roads by longitudinal slope.As shown in figure 1 .

\section{MAIN TECHNICAL STANDARDS}

the crowd load:3.0 kN/m²

basic wind speed design: $26 \mathrm{~m} / \mathrm{s}$;

Seismic load: the seismic intensity is 7 degrees, the cycle of characteristics is $0.40 \mathrm{~s}$;

bridge deck width: main bridge pavement width is $10 \mathrm{~m}$, there is $0.5 \mathrm{~m}$ decoration bar on each side of the bridge, the bridge is total $11 \mathrm{~m}$ wide;

the bridge longitudinal slope:main bridge is controlled by $5 \%$;

the deck transverse slope: two-way $1 \%$;

flat vertical curve: the centerline is the curve, the curve radius $\mathrm{R}$ is $154.41 \mathrm{~m}$;

design safety levels:one-level

design load: city-B

\section{STRUCTURAL DESIGN}

\section{A. Main Arch Design}

This bridge is asymmetric basket type arch bridge that the two pieces of independent steel box arch rib was connected by wind brace, two pieces of the main arch rib are leaning inward. The conjoined main and deputy arch of each arch rooted underground alternately,which are the same goals and supplement and complement to each other.Arch rib is out-of-plane large cantilever model that is divided into steel box arch rib section and steel-concrete composite structures section.

The arch axis is catenary that its coefficient $\mathrm{m}$ is $1.756 \mathrm{~m}$,calculated span of two pieces of independent steel box arch rib are respectively $176.26 \mathrm{~m}$ and $164.10 \mathrm{~m}$, the rise is $37 \mathrm{~m}$, rise-span ratio are $1 / 4.90$ and $1 / 4.56$ respectively ${ }^{[1-3]}$. Within the arch plane, the medial arch rib use circular curve with $\mathrm{R}=125 \mathrm{~m}$, and the lateral arch rib is made up of two circular curve with $\mathrm{R}=198.61 \mathrm{~m}$ and $\mathrm{R}=205 \mathrm{~m}$, respectively.as shown in Fig. 1 .

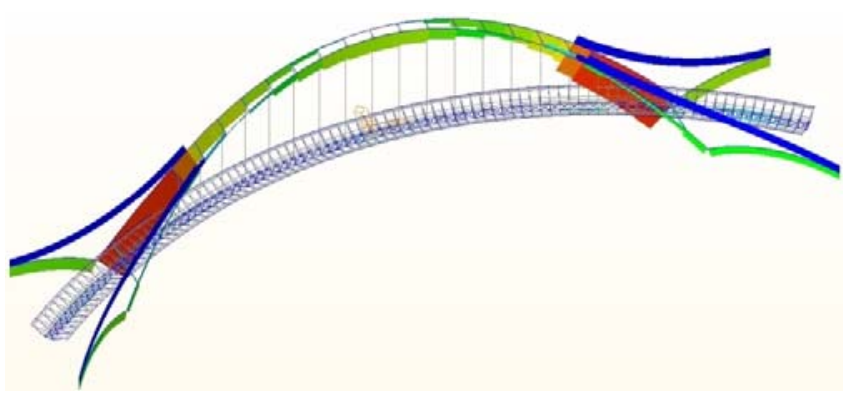

Fig. 1 Elevation of bridge 
Steel box arch rib section is single cell and single box section, sectional size is $1.8 \mathrm{~m} \times 2.4 \mathrm{~m}$, as shown in Fig. 2 . In order to improving stability of arch bridge, the arch rib section of arch foot adopts composite structure of steelconcrete, the strength grade of concrete is C50.In order to reduce the wind resistance and improve the visual effect, arch box corners adopt cutting Angle design, cutting Angle size is $15 \mathrm{~cm} \times 15 \mathrm{~cm}$. the thickness of steel box arch rib is $20 \mathrm{~mm}$, the web install longitudinal stiffener with $16 \mathrm{~mm} \times 150 \mathrm{~mm}$. the interval of longitudinal stiffener and diaphragm plate on the web are $0.4 \mathrm{~m}$ and $3.75 \mathrm{~m}$, respectively. in order to avoid structure complicate for chamfering area and ensure welding construction space, the longitudinal stiffening rib on the web are parallel to the roof and floor of steel box.
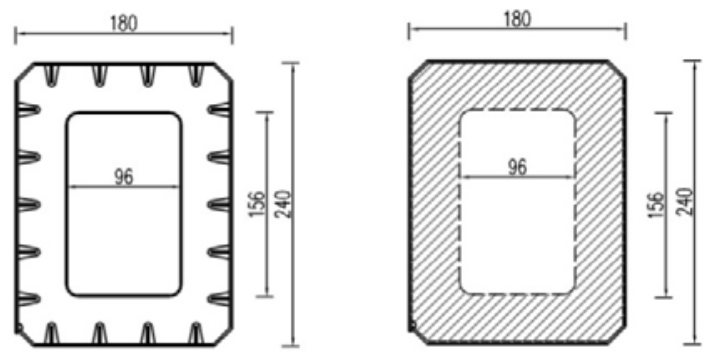

Fig. 2 Section of Steel Box Arch Rib

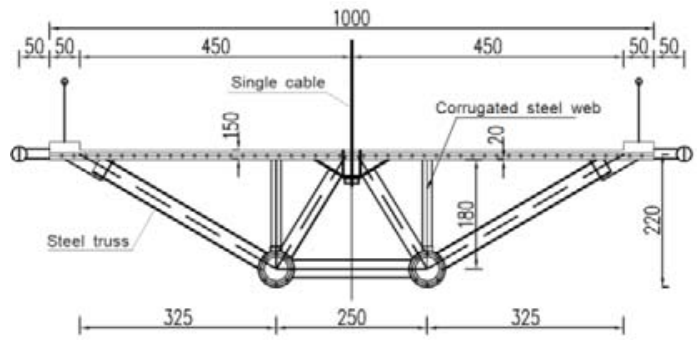

Fig. 3 Section of Main Girder

\section{B. Design of Main Girder}

Main girder is corrugated steel webs-truss composite structure, the central line of main girder is composed of circular curve with $\mathrm{R}=154.4 \mathrm{~m}$ and $\mathrm{R}=188 \mathrm{~m}$. thickness of top plate of main girder is $20 \mathrm{~mm}$, pavement layer uses C50 concrete, thickness is $15 \mathrm{~cm}$. Long of lateral cantilever girder is $3.75 \mathrm{~m}$, bracing is set in main girder every $2.5 \mathrm{~m}$, which specification is $\varphi 299 \times 16 \mathrm{~mm}$, lower chord of truss uses steel tube with $\varphi 600 \times 16 \mathrm{~mm}$, which infuse C50 micro expansive concrete, in addition, the material of top plate, bracing and lower chord use Q345qC.The web is corrugated steel webs that its center distance is $2.5 \mathrm{~m}$, wave length, height and thickness are $1.0 \mathrm{~m}, 20 \mathrm{~cm}$ and $16 \mathrm{~mm}$, respectively. In addition, the post pouring layers connect with main girder roof through the stiffener and shear stud. oblique bracing with $\varphi 245 \times 12 \mathrm{~mm}$ is designed between the top plate and lower chord, and lateral bracings connect with two lower chord, their size are $\varphi 299 \times 12 \mathrm{~mm}$. Forming a triangular section in the box which can improve the local anti torsion ability of main girder ${ }^{[4-5]}$. as shown in Fig. 3 .

\section{Suspender Design}

In order to make the bridge with the main arch without mutual interference,the central axis line of bridge is the circular curve of $\mathrm{R}=188 \mathrm{~m}$. A standard corrugated steel webs-truss segment is designed from center of axis to both ends of main beam every $2.5 \mathrm{~m}$, and a suspender is set every $7.5 \mathrm{~m}$, a total of 17 .

The suspender wire adopts extruded double large pitch twisted steel cable, each suspender steel cable is made up of $109 \Phi 7 \mathrm{~mm}$ of galvanized high strength low relaxation prestressed steel wire, standard strength fpk $=1670 \mathrm{MPa}$, which use double protective layer of high density polyethylene. as shown in Fig. 1.

\section{Material and Performance}

TABLE I. THE STRENGTH INDEX OF CONCRETE

\begin{tabular}{cccccc}
\hline \hline \multirow{2}{*}{ Type } & \multicolumn{2}{c}{ Design strength $/ \mathrm{MPa}$} & \multicolumn{2}{c}{ Standard strength $/ \mathrm{MPa}$} & \multirow{2}{*}{ Elasticity modulus $/ \mathrm{MPa}$} \\
& Axial compression & Axial tensile & Axial compression & Axial tensile & \\
\hline C40 & 18.4 & 1.65 & 26.8 & 2.4 & $3.25 \times 10^{4}$ \\
C50 & 22.4 & 1.83 & 32.4 & 2.65 & $3.55 \times 10^{4}$ \\
\hline \hline
\end{tabular}

TABLE II. THE MECHANICAL PROPERTIES OF STEEL WIRE CABLE

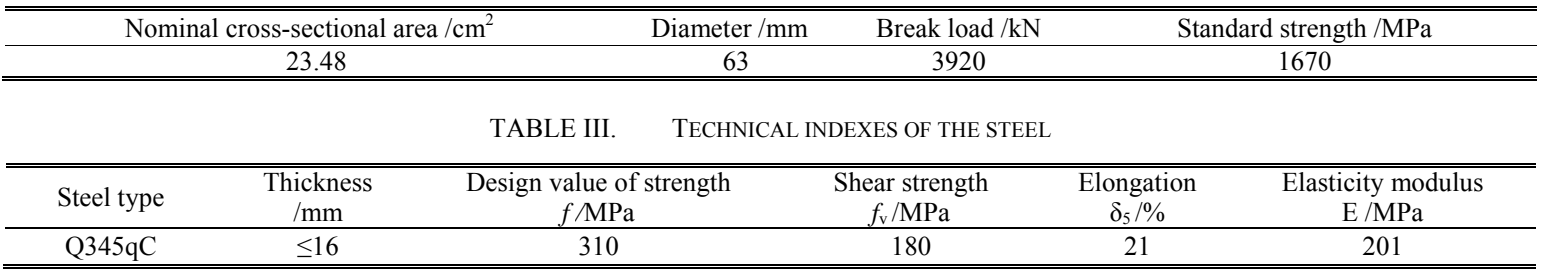




\section{CONCLUSION}

1) The bridge is optimal designed to be a flying swallow type curve special-shaped composite arch bridge and the bending moment and stress of cross section in main arch rib is small, which solves the following key technical problem: the maximum axial pressure and tension in arch rib and horizontal thrust of arch foot ,etc.

2) Main girder adopts corrugated steel-web and cantilever truss composite structure, which can reduce the dead weight of beams, bring the function of all materials into full play and improve the stability of structure, which can effectively resolve the problem of the longitudinal shearing and transverse bending, increase the width of deck and add to the beauty of the city ${ }^{[6-9]}$.

3) As can be seen from the results of the structural analysis, it is an advantage of good stiffness and strong stability. The design of space curved surface improves whole torsional capacity ${ }^{[10-12]}$.

\section{REFERENCE}

[1] Guan.L,Wang.Y. Optimize the arch axial coefficient of CFST arch bridge[J].Sichuan Architectue, 2007,(03): 106-107.

[2] Li.Y, Chen.Y.Y, Nie.J.G, et al. design and application of Steelconcrete composite bridge [M].Beijing, Science Press,2002: 113-116.

[3] Ding.F.X.The study of design method and mechanical behavior on CFST structure[D].central south university,2006.

[4] Li.Y, Nie.J.G, Yu.Z.W, Chen.Y.Y. The Stiffness study of Steelconcrete composite beam[J].Journal of Tsinghua university, 1998,38(10):38-41.

[5] Li.Y, Nie.J.G,Chen.Y.Y,etc.Design and Study on Shenzhen Rainbow Bridge [J]. China Civil Engineering Journal, 2002, 35(05):52-56.

[6] Wan, S., Tang, Y. and Wang, J.S. Experimental test of structural property of prestressed concrete box-girder with corrugated steel webs[J]. Journal of Nanjing University of Science and Technology, 2004, 28(5): 498-501.

[7] JT/T 784-2010. Corrugated steel webs in composite structure bridge[S]. Beijing: China Communications Press, 2010.

[8] Chen, B.C., Chen, Y.Y. and Ling, S. Investigation and analysis of bridges with corrugated steel web[J]. Journal of China \& Foreigner Highway, 2010, (1): 109-118.

[9] Liu, S.M., Zhao, S.B., and Li, X.K. Analysis of static, dynamic and seismic performance of long span irregular-shape pedestrian cablestayed bridg[J]. Bridge Construction, 2012, 42(4): 45-50.

[10] YUN.D.Static and aseismic behavior of large span half-through CFST arch bridges[D]. Harbin Institute of Technology, 2007.

[11] He.W, Zhao.SH.B,Yang. J, ZH,etc. Large-span wide double basket arc bridge dynamic characteristics and seismic performance [J].Journal of Vibration, Measurement\&Diagnosis, 2010,30(6): 32$35+109-110$.

[12] Chen Baochun, Zheng Huaiying. Analysis of bridge state on" FlyBird-Type" CFST art bridge[J].Journal of China \&Foreign Highway, 2006,26(6):43-45. 